

\section{Accounting Education Approach in the Context of New Turkish Commercial Code and Turkish Accounting Standards}

\author{
Dr. Cevdet Kizıl \\ Dr. Ayşe Tansel Çetin
}

Ahmed Bulunmaz

\section{INTRODUCTION}

Rapid improvement in information technologies, globalization, fierce competition, demands of creditors, internationalization of capital, developments in financial instruments and highering risks have made the presentation of financial statements more important. Today's business world demands comparable financial statements. Moreover, the process of adaptation to the European Union (EU) requires publicly traded companies, banks, insurance firms as well as Small and Medium Sized Enterprises (SMEs) to implement accounting standards. (Kizil A., Fidan, Kizil C., Keskin, 2013).

Additionally, the new Turkish commercial code requires companies operating in Turkey to implement Turkish Financial Reporting Standards (TFRS) and Turkish Accounting Standards (TMS), that are parallel to International Financial Reporting Standards (IFRS) and International Accounting Standards (IAS) (Kizil A., Fidan, Kizil C., Keskin, 2013).

Basel Committeee on Banking Supervision has also stated that they support the implementation of IFRS (Gökçen, Akgül, Çakıcı, 2006). Academicians, practitioners, accounting lecturers and business management should be well informed of accounting standards (Örten, Kaval, Karapınar, 2007). Analyzing the impact of new Turkish commercial code and Turkish accounting standards on accounting education is an essential source of motivation for this research because of mentioned reasons.

\section{LITERATURE REVIEW}

It has been stated in a previous research that, Turkey, business world and accounting atmosphere are experiencing big changes as a result of implementation of International Financial Reporting Standards (IFRS), International Standards on Auditing (ISA), and new Turkish Commercial Code (Karğın and Aktaş, 2012). It is thought that new code shapes the commercial law concerning transparency, auditing, and reliability.
Necessities of preparing financial statements parallel to IFRS and ISA present several subjects such as internal controlling, independent auditing, and risk management which create many responsibilities for managers, accounting managers and professionals (Karğın and Aktaş, 2012).

Implementation of IFRS and the new Turkish Commercial Code forces new policies, strategies, and applications in business life. Managers who are obligated to maximize firm's value for shareholders are obligated to implement IFRS and the new code and simultaneously they experience global financial crises and big rivalry (Karğın and Aktaş, 2012). Another former research indicates that, IFRS have seriously been brain-stormed and implemented by several countries and authorities after the Enron Case. International standard setters and law smaker of the mentioned nations are making it a necessity to implement IFRS in practice (Pekdemir and Turel, 2010). After that, a study run by American Institute of Certified Public Accountants (AICPA, 1998) indicates that CPAs must have specific expertise like communication, leadership, strategic thinking, and customer concentration to stay competitive in the organization environment besides traditional accounting and auditing information (Bui and Porter, 2010). Institute of Chartered Accountants in Australia (ICAA, 1998) explains the abilities for future accountants as strategic skills, accounting and finance skills, people skills, and information technology skills.

Institute of Chartered Accountants in England and Wales (ICAEW, 1996) expresses that, in addition to the classical jobs accountants must run, they must also integrate technical expertise with strategic vision and strategic planning (Howieson, 2003). Bui and Porter (2010) pointed out the demanded competencies which professional accountants must own. Parallel to this, accountants must reflect technical accounting skills, a broad business viewpoint and general business expertise, and personal competencies. Personal competencies cover strategic thinking and management, communication expertise, leadership expertise, interpersonal expertise, and the capacity of adopting to fast changing business atmosphere.

Demir and Süer Öztek (2006) researched the effects of Turkey's accession to European Union (EU) concerning accounting education. Parallel to their results, majority of academicians who did take the questionnaire thought that future accountants should not only be armed with the courses to have basic accounting knowledge. They must also be armed with courses and teaching methods to gather strategic thinking expertise. Karğın and Aktaş's research (2012) also points out that, congoing development of accounting education will assist new graduates to be successful in their jobs. Moreover, CPA trainees and CPAs must receive life-long education for improving strategic thinking competencies and to get used to the changes in accounting standards. Some level 
of training programs must especially exist, that are developed by the profession bodies (For example Public Oversight Accounting and Auditing Standards Authority and the Union of Chambers of Certified Public Accountants and Sworn-in Certified Public Accountants of Turkey).

Some scholars do also argue that, the fall of the Soviet Union was because of the failure to distribute resources efficiently under a socialist accounting system (Sennholz 2002; Rothbard 1991). Preobragenskaya and McGee did run a study about the link between IAS and foreign direct investment (FDI) in Russia (2003a) and on the situation of auditing in Russia (2003b). Their FDI research indicated that, the low trust level in Russian financial statements was restricting inflows of foreign capital. Their audit research also showed that, the level of auditing in Russia can not yet be compared to western standards.

According to another study, the legal atmosphere should be learned parallel to each country's legal and financial regimes. Furthermore, as accounting is getting more and more global every day, the effect of International Financial Reporting Standards and law reforms like the Sarbanes-Oxley Act in the US are basic issues to understand the impacts that are experienced by accountants globally. This topic must be an ongoing issue for continuing education (IFAC, 2005).

Parallel to former studies, potential advantages of IFRS practice cover greater transparency in financial statements (Jermakowicz \& Gornik-Tomaszewski, 2006; Tyrrall, Woodward, \& Rakhimbekova, 2007), lower cost of capital (Jermakowicz \& Gornik-Tomaszewski, 2006; Jones \& Higgins, 2006) enhancing comparability of financial statements (Aljifri \& Khasharmeh, 2006), increasing internal reporting reliability (Ballas et al., 2010), attracting foreign direct investment (Aljifri \& Khasharmeh, 2006; Tyrrall et al.,2007), providing greater access to capital (Ballas et al., 2010; Jermakowicz \& Gornik-Tomaszewski, 2006; Jones \& Higgins, 2006), applying for ratings to international agencies (Tyrrall et al., 2007), easing financial reporting requirements for international corporations (Tyrrall et al., 2007), facilitating the quotation of shares on foreign stock exchanges (Jermakowicz \& Gornik-Tomaszewski, 2006; Jones \& Higgins, 2006; Tyrrall et al., 2007), and satisfying the requirements of supranational institutions (i.e. World Bank) for granting financial aid (Tyrrall et al., 2007).

Uyar and Güngörmüş 's (2013) research aimed to investigate basic knowledge and perceptions of accountants regarding IFRS for SMEs. The respondents were not highly informed about the omission of certain topics in IFRS for SMEs. Their awareness of valuation methods/concepts in IFRS for SMEs was at a moderate level.

Inadequacy of accounting personnel's training and lack of training programs arranged by professional bodies were considered to be the most serious barriers concerning the practice of the standards. The majority of the participants were not informed about the key distinctions between full IFRS and IFRS for SMEs and simplifications made in IFRS for SMEs (Uyar and Güngörmüş, 2013). Accounting professionals who were trained about IFRS for SMEs and the employees of Big4 auditing firms were more knowledgeable about the standards in comparison to others. Education level and experience of respondents had partial positive impact on knowledge of the standards (Uyar and Güngörmüş, 2013).

Jackling, Howieson and Natoli (2012) reported that, the potential effect about accounting education in IFRS implementing countries do differ seriously because not all nations begin the implementation steps from the same starting point. Accounting educators in the world must improve their familiarity with the principles-based approach to teach IFRS. Teaching resources, educational research and Continuing Professional Development operations concerned with principles-based approach to teach IFRS are a must for educators to improve the learning experience of students considering the transmission from a rules-based to a principles-based set of accounting standards (Jackling, Howieson \& Natoli, 2012).

The preparedness of accounting educators in the United States to lecture IFRS has been often questioned (Leone 2008; Mintz 2009; Munter and Reckers 2009; KPMG and AAA 2011). Starting from 2008, KPMG and the American Accounting Association (AAA) have surveyed together the accounting educators in United States annually to detect where IFRS-related education stands at collegiate accounting curricula (KPMG and AAA 2011). The latest of the mentioned surveys was run in 2011. These surveys have pointed out serious uncertainty concerning United States academicians as to the likely implementation of IFRS for domestic goals and in their reactions to that potential event.

For example, in $200968 \%$ of the individuals taking the questionnaire (out of a total of 500 respondents) thought that the United States would implement IFRS domestically, but this had decreased to 54\% in 2011 (out of a total of 638 respondents). Approximately, $60 \%$ of the individuals taking the questionnaire in 2011 thought that implemention of IFRS was not a top priority for the SEC and only $40 \%$ reported that they had seriously integrated IFRS into their curriculum (KPMG and AAA 2011). Several disincentives and adoptation issues have been 
detected by the help of mentioned surveys and by remaining authors.

These also cover the issue of creating a place in a curriculum for IFRS at the same time US GAAP remain the required standards (Munter and Reckers 2008; KPMG and AAA 2011). This problem is actually related to educators who consider the teaching of accounting as being based on rules instead of principles. Definitely, there also exists the problem related to the ageing demographic of accounting academics. This means a decreased number of academicians who cover teaching. It is stated that, there is no or very little source of encouragement for academicians who are close to retirement to 'regain' a new set of standards) (Leone 2008; Munter and Reckers 2009). According to the 2011 KPMG/AAA questionnaire, $91 \%$ of the accounting educators reflected no practical experience concerning the implementation of IFRS. Furthermore, improving 'new' materials and making textbook authors/publishers to integrate IFRS material is considered as a tough issue in the United States since there exists less encouragement to make changes until the SEC requires the domestic implementation of IFRS (Leone 2008; Munter and Reckers 2009; KPMG and AAA 2011). Besides, academicians in United States defend that, they are not adequately supported to make the required changes to their curricula since university managers can not clearly perceive the future effects of IFRS implementation (Munter and Reckers 2009; KPMG and AAA 2011). At last, one big source of demotivation to integrate IFRS into US curricula is that many programs are developed for students to help them only succeed in the CPA exam (Leone 2008; Mintz 2009). Thus, curricula will probably not be changed until the exam is altered to cover. (Leone 2008). However, the 2011 KPMG/AAA questionnaire showed that, $61 \%$ of individuals who took the questionnaire thought that, the CPA exam would cover an important part of IFRS in approximately three years (KPMG and AAA 2011).

Coetzee and Schmulian (2012) indicate that accounting educators should take advantage of many innovative techniques of pedagogy, like simulations, role playing, problem-based learning, case studies with alternative solutions and oral presentations. Research by Henry and Dodson (2009) distributed a survey to find out the opinions of college business majors and their attitude toward accounting fraud and ethical education. Their findings suggested that, ethics education did have a positive effect on the reduction of accounting fraud. Malone (2006) stated with this research that, more education in ethics could and would improve decisions of accountants and other professionals.

Black at. al. (2010) investigated the benefits of professional ethics training on three levels of ethical improvement, which are Moral Motivation, Moral Reasoning, and Ethical Intention. They did find important results, which show that professional ethics training did have an impact on practicing accountants based on their cultural history, other ethics training, and demographic features.

Black et. al. (2010) pointed out that professional ethics training has an impact on the moral motivation dimensions especially for individuals coming from Middle East and Southeast Asian countries. Moreover, professional ethics training had greater impact on moral reasoning for individuals who expressed that they are not religious. Besides, if an individual was from a culture with high Uncertainty Avoidance [which means they are more in favor of structure and rules rather than uncertainty], then professional ethics training had more impact in terms of moral reasoning.

Results of Black et. al. (2010) indicated that individuals who took part in ethics standards setting and ethics training had to be knowledgeable that ethics education effectiveness did change based on the ethical development level and was influence by cultural issues in addition to demographic issues, like gender, educational stage, age, and religiosity besides the culture and demographics of the students who get the training. The impact of training would be different based on the mentioned issues. Ezeani Nneka and Rotimi (2012) indicated that, first of all the curricula of Nigerian institutions should be controlled and investigated to integrate IFRS. That way, accountants and auditors would get familiar with IFRS guidelines and standards. Garuba and Donwa (2011) also defends the same perspective, stating that there is a necessity to educate the educators to increase the knowledge about IFRS.

Adhikari, Flanigan and Tondkar's research (1999) showed that, some steps had been taken to internationalize the accounting curriculum. However, there is still a long way to go in terms of internationalizing the accounting curriculum. One eyecatching point is that, until that time, more steps are taken at the graduate level compared to the undergraduate level for both non-US and US institutions. Also, some variances were detected between non-US and US schools regarding the considered significance of specific international subjects and underlying motivation for internationalization.

Adhikari, Flanigan and Tondkar's research (1999) also reflected that, both non-US and US schools considered the less number of international accounting topic in doctoral programs and the weakness of faculty expertise as important problems for internationalization. The mentioned two factors must be resolved if more steps in internationalization of the accounting curriculum needs to be taken. Aktaş (2013) emphasized that, education was among the principle issues related to the application of International Financial Reporting Standards (IFRS). Because IFRSs were principle-based, changing 
continuously as a result of improvements, "Frameworkbased Teaching" method was advised for teaching them to both professional accountants and future accountants.

Fowler, Tan and Hawkes' (2002) study showed that accounting educators gave more importance to recent management accounting methods than practitioners. This, their research results were not paralel to former criticisms that the management accounting curriculum was not recent as practice. Results from the mentioned research also indicated that, practitioners still preferred traditional over contemporary management accounting methods for use in their firms and to educate students. On the other hand, academics preferred contemporary methods.

Yildiz (2004) underlined with his research that, number of undergraduate students in the faculty of economics and four year vocational schools was high, and most programs also had evening education. Thus, the workload of assistant professors in Turkey was high, limiting their research abilities and possibilities. Research by Durak (2009) showed that, $40 \%$ of accounting professionals believed they had a general knowledge of accounting during their two years vocational school education. Also, $12 \%$ of accounting professionals reported that they had a low level of accounting knowledge through their vocational school years. In terms of accounting professionals with undergraduate diploma, 52\% said they had general knowledge of accounting through their four years in the university. Also, $12 \%$ stated that they had a low level of accounting education and knowledge during four years.

Research by Durak (2009) also showed that, Turkish firms did not give adequate importance to accounting education and they generally prefered to employ experienced staff. This was causing the firms to be unfamiliar to the concept of accounting education. Durak (2009) defended that Turkish firms had to focus more on accounting education and they had to implement innovative traning programs towards accounting professionals. Private sector-university cooperation was required at that point and current ties had to be strengthened. That would help accounting theory and practice to complete each other in Turkey.

Yereli at. al.(2010) analyzed and investigated papers with the topic of "Accounting Education" which were published between the years 1997-2008 in international journals. 789 papers had been investigated concerning international accounting education. As a result of investigation, they realized that the number of ampiric research was higher than the number of theorical studies for 1997-2008. Concerning the categorization of papers into their topics, the most frequent studied topic was "Curriculum and Instructions". Concerning the emphasized years, it was detected that "Descriptive Model" was the most preferred model. Also, "The Survey
Method" was the most frequently used data collection technique in the papers. The papers with more than two authors were higher than others in mentioned years.

Miller, Van Daniker and Relmond (1999) did run a questionnaire to discover the changes that were observed in government accounting education in the last 5 years and others which would happen in the next 5 years. A questionnaire containing 21 questions was distributed to 517 members of the Government/Not-For-Profit Section of the American Accounting Association to obtain information. The results of the survey showed that government accounting education was in the midst of a number of significant changes and that these changes would continue to evolve. One of the most significant findings of the survey was the increasing use of the Internet in government accounting courses.

Süer's study (2007) observed the students at 11th class in The Commerce Profession High Schools and the teachers who did teach accountancy at these schools in İstanbul between 2006-2007 education years. Prepared inquiry was applied to 411 students at 7 random selective schools and 147 profession teachers at 18 random selective school. Then the information from the inquiry was processed at SPSS software. The responses, the percent and the frequency graphics were prepared. At the and of the observation, the information which was received from the observation showed that there were lots of problems concerning accountancy education at The Commerce Profession High Schools.

Gökgöz (2007) applied a questionnaire consisting 26 questions to 755 students who were trainees in different regions of İstanbul in order to determine the problems which are confronted with training education in organizations. When the questionnaire form was evaluated, it was determined that trainees choose trade vocation high schools for variety of reasons which are inappropriate with the school's foundation aims. Problems detected were deficiency of materials at school, the inadequacy of teachers, the inadequacy of the education at school, the inappropriateness of the training place for improving, no integration between the school and practice, no cooperation between the school and business world, the fact that trainees work in other departments apart from their own fields, trainees are not paid the amount of money that they deserve according to their work and the inappropriateness of training time.

Marshall et. al. (2010) did also run a questionnaire and investigated the thoughts of a group of accounting academicians concerning the value of the CPA title as a teaching measure. The results showed that teaching experience was the most effective factor to acquire all of the assessed abilities. However, the performance concerning to run a research was an exception, since 
doctoral program preparation was the most important factor here. Stolowy and Tenenhaus's research (1997) took advantage of a questionnaire and provided information concerning two issues. First of all, although some variances were observed between nations, most courses were specific, contrary to general lectures uniting specific international accounting issues. Second, a serious number of institutions did achieve to include both comparative dimensions and accounting aspects of multinational firms.

Ayboğa's research (2002) stated that, accounting practices in Turkey had differences due to the legal arrangements. On the other hand, Turkey's accounting practices were under the effect of tax regulations. Prepared financial schedules did not show the real situation of the establishments and present important differences, compared with international practices. Ayboğa (2002) also reported that, in the process of globalization, Turkey needed a common accounting language either at national level or at international level. This common language could be provided with national accounting standards which is harmonious with international accounting standards. For adapting developments in the world, professional trainings of Accounting Professionals had gained much importance.

\section{Data and Methdology}

Data were collected from vocational school and undergraduate students in Turkish universities. As a result of the study, 513 responses were gathered via the questionnaire. The sample includes students from Yalova University, Marmara University, Atatürk University, Bayburt University, Ordu University, Sakarya University, Uludağ University and Van 100. Y1l University. Questionnaires were distributed with cargo (carriers) and also personally.

The research questions are listed below in consequence. The questions included in the questionnaire are parallel to the research questions. Since the first three survey questions are concerned with demographical information, they are not taken into consideration as research questions. Thus, the research questions start with Q4.

- $\quad$ Q4= Are Turkish Commercial Code and Turkish Accounting Standards included to higher education curricula as mantatory or elective courses?

- $\mathrm{Q} 5=$ Is it beneficial to include Turkish Commercial Code and Turkish Accounting Standards to higher education curricula?

- $\mathrm{Q6}=$ Is the ratio of Turkish Commercial Code and Turkish Accounting Standards courses sufficient to all courses included in higher education curricula?

- $\quad$ Q7= Do Turkish accounting academicians provide detailed information to students about Turkish Commercial Code and Turkish Accounting Standards during the courses?

- $\mathrm{Q} 8=$ Is it advantageous for university students to gather a deep knowledge of Turkish accounting standards and Turkish auditing standards through their education?

- $\mathrm{Q} 9=$ Are students taught in detailed about Turkish accounting standards and Turkish auditing standards through their education?

- $\mathrm{Q} 10=$ Do Turkish university students take multidisciplinary international business courses that cover accounting topics?

- $\mathrm{Q} 11=$ Do Turkish universities teach international accounting to students separately as a course?

- $\mathrm{Q} 12=$ Do Turkish universities teach international tax law to students separately as a course?

- $\mathrm{Q} 13=$ Do Turkish universities integrate international dimension and perspective into accounting courses?

- $\mathrm{Q} 14=$ Do Financial (General) Accounting courses in Turkey include some topics and elements of international accounting?

- $\quad \mathrm{Q} 15=$ Do Turkish universities offer curricula and courses which never include international accounting subjects?

- $\mathrm{Q} 16=$ Are contemporary issues related to accounting courses discussed in Turkish universities?

- $\mathrm{Q} 17=$ Are fundamental changes required for accounting education?

- $\mathrm{Q} 18=$ Are partial changes required for accounting education?

- $\quad \mathrm{Q} 19=$ Should accounting education programs be designed specially, which supports the self learning and improvement of students?

- $\mathrm{Q} 20=$ Do accountants of future receive the required accounting background, which matches the increasing demand of society?

- $\quad \mathrm{Q} 21=$ Should accounting education programs primarily focus on national and international 
exams organized for employment opportunities?

- $\quad \mathrm{Q} 22=$ Should accounting education put more emphasis on tax practices and applications?

- $\quad \mathrm{Q} 23=$ Should accounting education give more importance to analysis and interpretation compared to recording and entries?

- $\quad$ Q24= Should students be trained in a specific way which will make them very familiar with professional accounting and auditing standards?

- $\mathrm{Q} 25=$ Should accounting education put more weight on written and oral communication ability?

- $\quad$ Q26= Should accounting education concentrate more on personal skills?

- $\quad$ Q27= Should accounting education give more importance to mental ability?

- $\mathrm{Q} 28=$ Should accounting education value ethical concepts more?

- $\quad$ Q29= Should accounting education go through fundamental changes in teaching/lecturing techniques?

- $\mathrm{Q} 30=$ Are current technical (technological) background in Turkish universities adequate for the implementation of teaching/lecturing techniques?

- $\mathrm{Q} 31=$ Is the number of accounting academicians in Turkish universities enough for the implementation of teaching/lecturing techniques?

- $\mathrm{Q} 32=$ Do the current teaching/lecturing techniques in Turkey encourage students to think and run brainstorming through courses?

- $\mathrm{Q} 33=$ Should accounting education and teaching the courses be based on problem solutions included in books?

- $\mathrm{Q} 34=$ Should group study and teamwork be implemented extensively for accounting courses?

- $\mathrm{Q} 35=$ Should case studies and role playing be implemented extensively for accounting courses?
- $\quad \mathrm{Q} 36=$ Are written projects and assignments a critical element of accounting courses in Turkey?

- $\quad$ Q37= Should internship be definitely included for accounting education?

- $\mathrm{Q} 38=$ Does the current grading system in Turkey motivate students to learn accounting?

- $\mathrm{Q} 39=$ Do the current practices and implementations encourage accounting academicians for a more effective accounting education in Turkey?

For this research, a total of 513 respondents did take the survey. 239 were males and 274 were females. In other words, $46.6 \%$ were male students and $53.4 \%$ were female students.

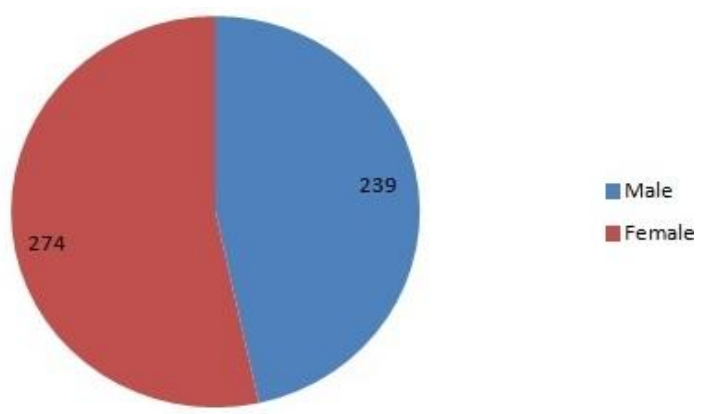

Figure 1: Demographics of Respondents Gender

In terms of study, 3 respondents were below age 18 (\%0.6), 404 were between the ages 18-22 (\%78.8), 101 were between $23-27$ (\%19.7), 3 were between the ages

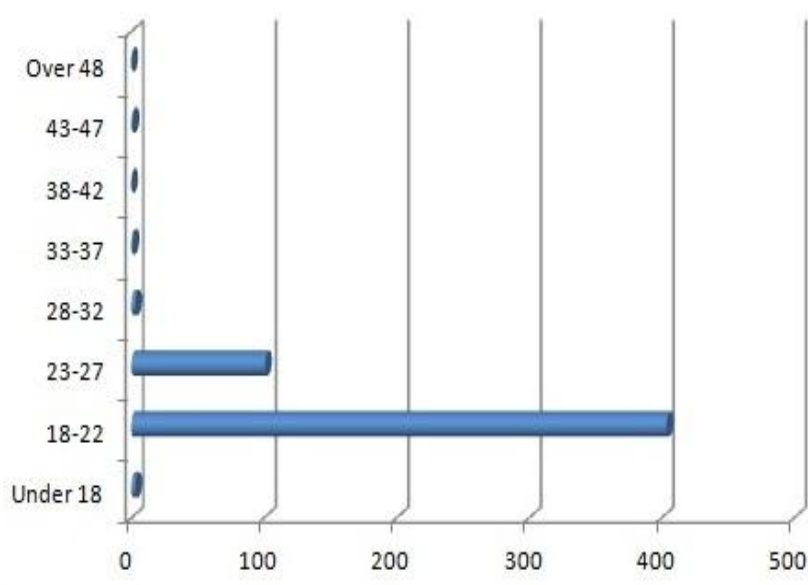

28-32 (\%0.06), 1 was between 33-37 (\%0.02), 1 was between the ages 43-47 (\%0.02).

Figure 2: Demographics of Respondents - Age 
This research was run at 9 different universities. 154 students from Yalova University, 130 students from Marmara University, 99 students from Bayburt University, 77 students from Ordu University, 48 students from Sakarya University, 2 students from Uludağ University, 1 student from Ankara University, 1 student from Atatürk University and 1 student from Van 100. Y1l University did participate in this study.

Figure 3. Demographics of Respondents Universities

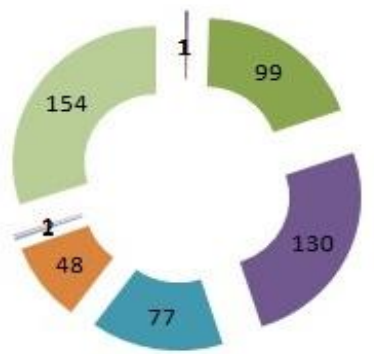

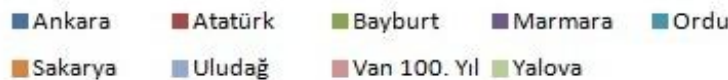

\section{Research Results}

The most important and eye-catching research results are indicated below.

Q4: Turkish Commercial Code (TCC) and Turkish Accounting Standards (TAS) are included to the curriculum in your university as mandatory or elective course?

$17.1 \%$ of respondents said they definitely disagree, $16.8 \%$ said they do not agree, $13.2 \%$ are indecisive, $11.2 \%$ said they agree and $14.3 \%$ said they definitely agree. Finally, 27\% of respondents did not answer this question

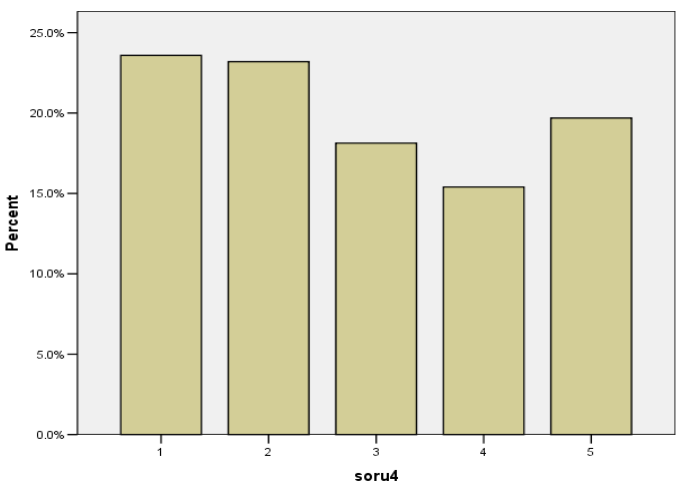

Figure 4. TCC and TAS are included to the curriculum in your university as mandatory or elective course?

Q5: Is it beneficial to include TCC and TAS to higher education curricula?

$8.8 \%$ of respondents reported that they never agree, $13.5 \%$ of respondents stated that they do not agree, $21.1 \%$ of respondents were uncertain, $30.6 \%$ did agree and $26.1 \%$ did definitely agree.

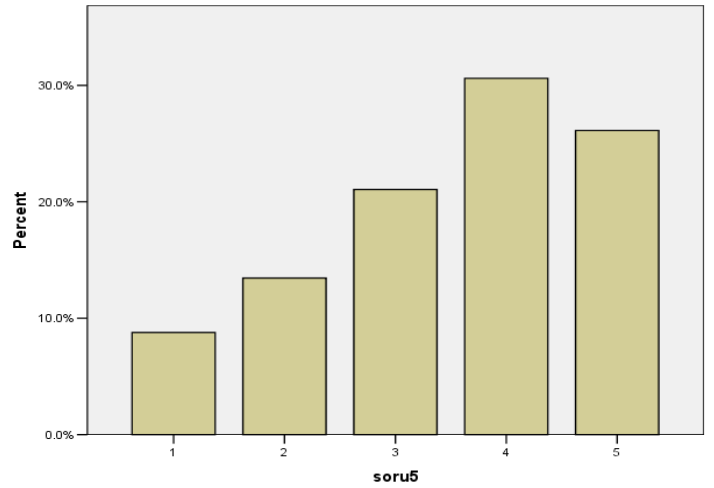

Figure 5: Is it beneficial to include TCC and TAS to higher education curricula?

Q6: Is the ratio of TCC and TAS courses sufficient to all courses included in higher education curricula?

$11.1 \%$ of respondents indicated that they definitely disagree, $23.4 \%$ indicated that they disagree, $37.6 \%$ of respondents were indecisive, $18.9 \%$ of respondents did agree, $9.0 \%$ of respondents did definitely agree.

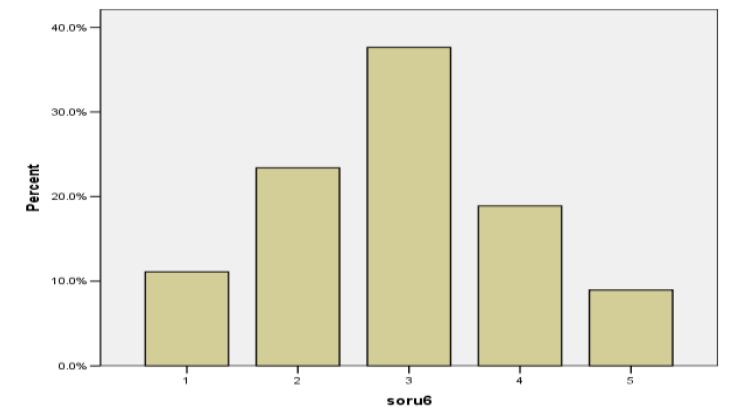

Figure 6: Is the ratio of TCC and TAS courses sufficient to all courses included in higher education curricula?

Q7: Do Turkish accounting academicians provide detailed information about TCC and TAS? 
$1.5 \%$ of respondents reported that they definitely disagree, $23.2 \%$ of respondents said they disagree, $33.1 \%$ were indecisive, $17.2 \%$ of students did agree and $9.0 \%$ of students did definitely agree.

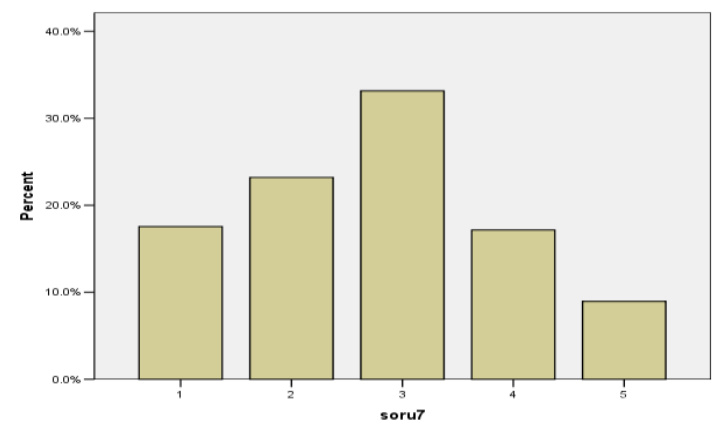

Figure 7. Do Turkish accounting academicians provide detailed information about TCC and TAS?

Q8: Is it advantageous for university students to gather a deep knowledge of TAS and Turkish auditing standards?

$8 \%$ of respondents answered that they definitely disagree. $12.7 \%$ did disagree. $18.1 \%$ could not make a decision. On the other hand, $34.5 \%$ of students did agree and $26.7 \%$ did definitely agree.

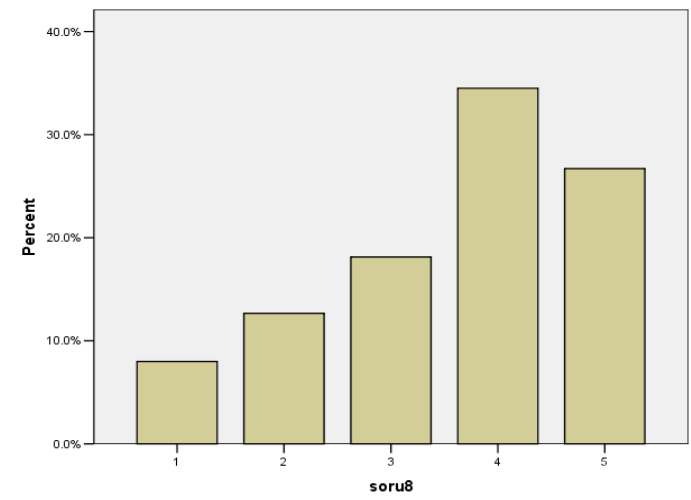

Figure 8. Is it advantageous for university students to gather a deep knowledge of TAS and Turkish auditing standards?

Q9: Are students taught in detail about TAS and Turkish auditing standards through their education?

$12.9 \%$ here did definitely disagree and $25.1 \%$ did disagree. $32.7 \%$ of students were indecisive. Also, $21.8 \%$ did agree and $7.4 \%$ did definitely agree.

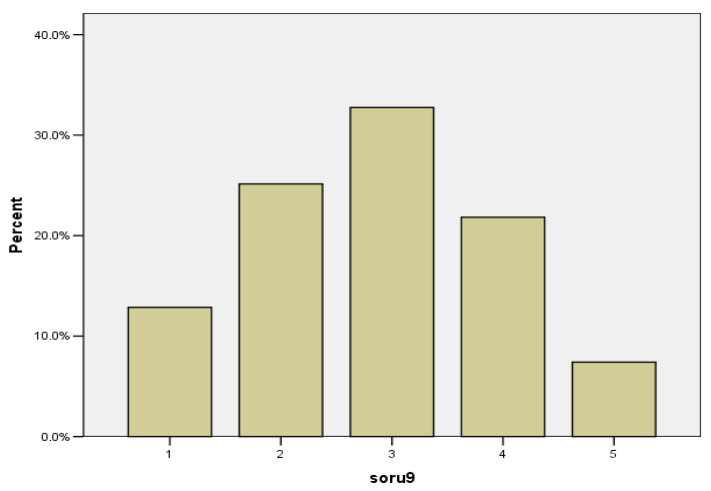

Figure 9. Are students taught in detail about TAS and Turkish auditing standards through their education?

Q14: Do Financial (General) Accounting courses in Turkey include some topics and elements of international accounting?

9.2\% of respondents did definitely disagree, $17.5 \%$ did disagree, $22 \%$ were indecisive, $34.7 \%$ did agree and $16.6 \%$ did definitely agree.

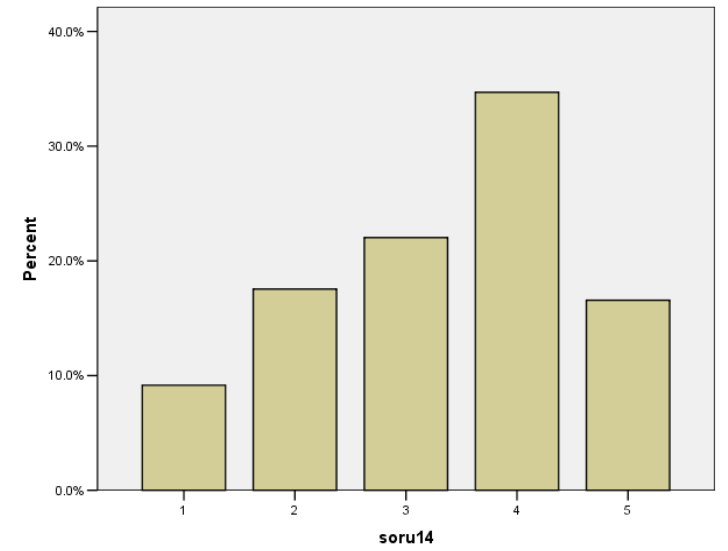

Figure 10. Do Financial (General) Accounting courses in Turkey include some topics and elements of international accounting?

Q16: Are contemporary issues related to accounting courses discussed in Turkish universities?

For this survey question, $11.5 \%$ said they definitely disagree, $20.7 \%$ mentioned that they disagree, $21.4 \%$ were indecisive, $28.8 \%$ agreed, $17.5 \%$ did definitely agree. 


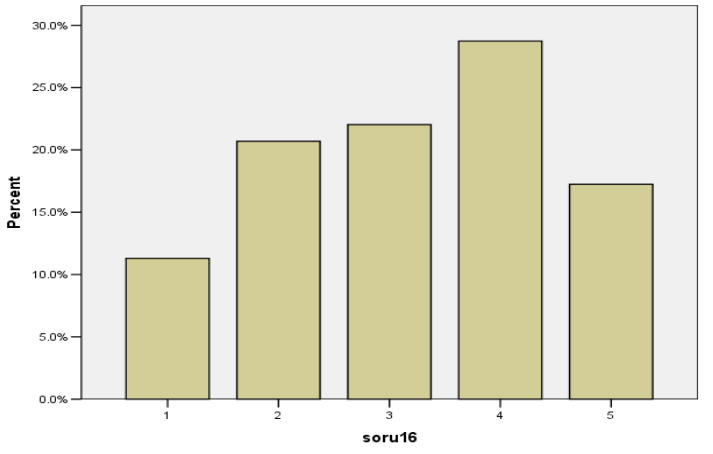

Figure 11. Are contemporary issues related to accounting courses discussed in Turkish universities?

Q21: Should accounting education programs primarily focus on national and international exams organized for employment opportunities?

Concerning this question, $5.7 \%$ of students defintely disagreed, $14.2 \%$ did disagree, $25.1 \%$ were indecisive, $30.2 \%$ did agree and $24.8 \%$ did definitely agree.

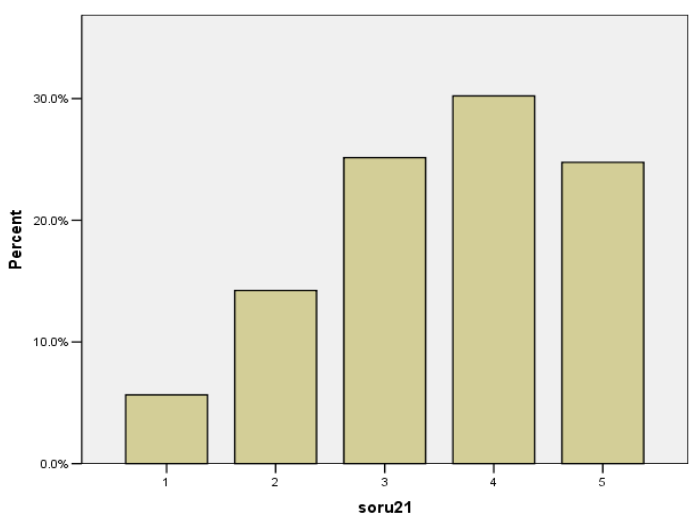

Figure 12. Should accounting education programs primarily focus on national and international exams organized for employment opportunities?

Q23: Should accounting education give more importance to analysis and interpretation compared to recording and entries?

Here, $5.1 \%$ of students did definitely disagree, $14 \%$ did disagree, $24.8 \%$ were indecisive, $33.5 \%$ did agree and $22.6 \%$ did definitely agree.

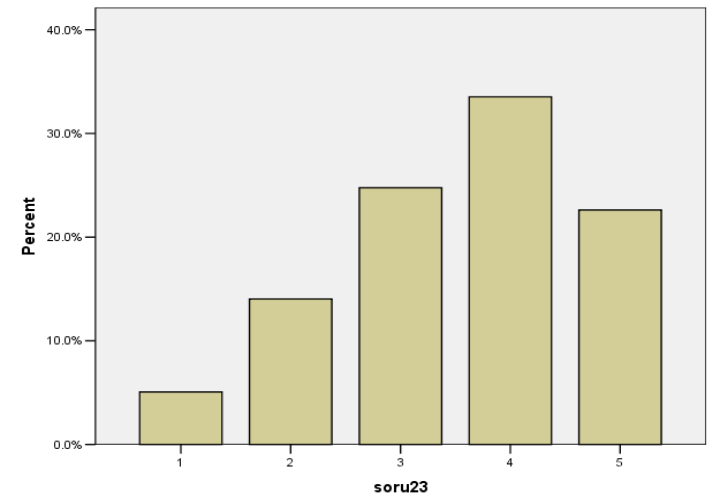

Figure 13. Should accounting education give more importance to analysis and interpretation compared to recording and entries?

Q24: Should students be trained in a specific way which will make them very familiar with professional accounting and auditing standards?

$5.5 \%$ of students did definitely disagree here. Additionally, $9.4 \%$ of respondents disagreed. 22.8\% could not provide a decision. However, $30.8 \%$ of students did agree and $31.6 \%$ did definitely agree.

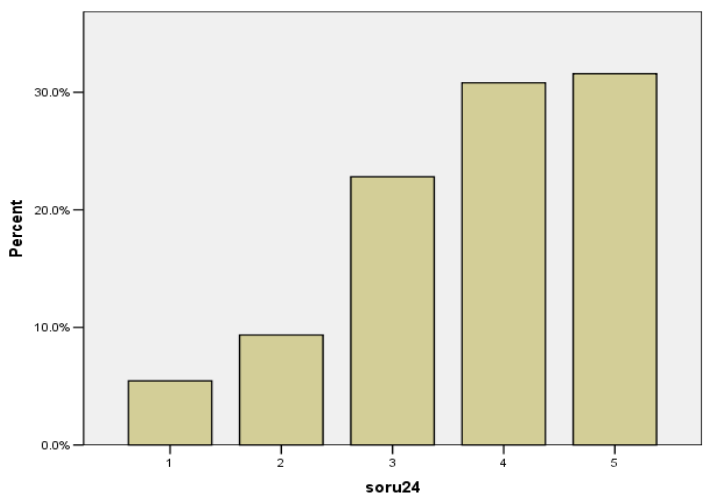

Figure 14. Should students be trained in a specific way which will make them very familiar with professional accounting and auditing standards?

Q28: Should accounting education value ethical concepts more?

For this question, $9.0 \%$ of students did definitely disagree, $15.2 \%$ did agree, $26.3 \%$ were 
indecisive, 29.8\% did agree and 19.7\% did definitely agree.

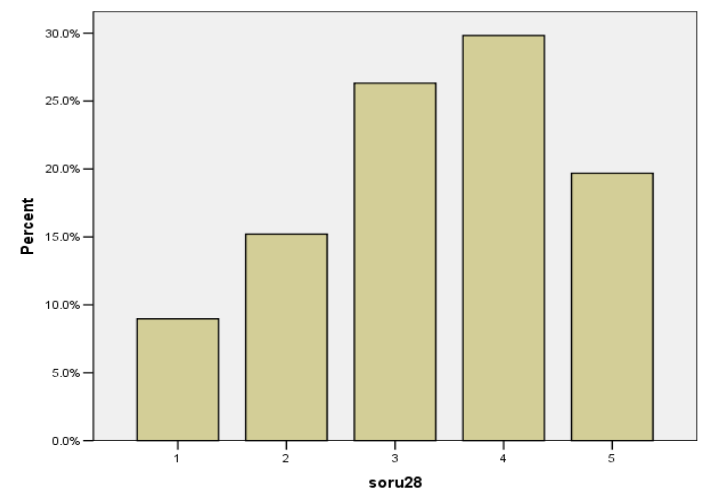

Figure 15. Should accounting education value ethical concepts more?

Q34: Should group study and teamwork be implemented extensively for accounting courses?

Here, $7.8 \%$ of students did definitely agree, $16.2 \%$ did agree, $25.1 \%$ were indecisive, $32.2 \%$ did agree and $18.7 \%$ did definitely agree.

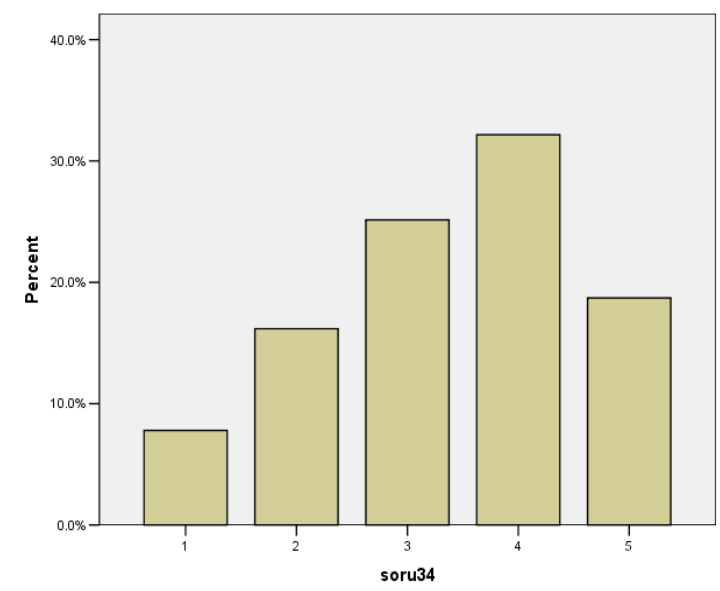

Figure 16. Should group study and teamwork be implemented extensively for accounting courses?

Q35: Should case studies and role playing be implemented extensively for accounting courses?

Parallel to responses of students, $4.9 \%$ definitely disagee, $11.9 \%$ agree, $28.1 \%$ is indecisive, $31.0 \%$ agree and $24.2 \%$ do definitely agree.

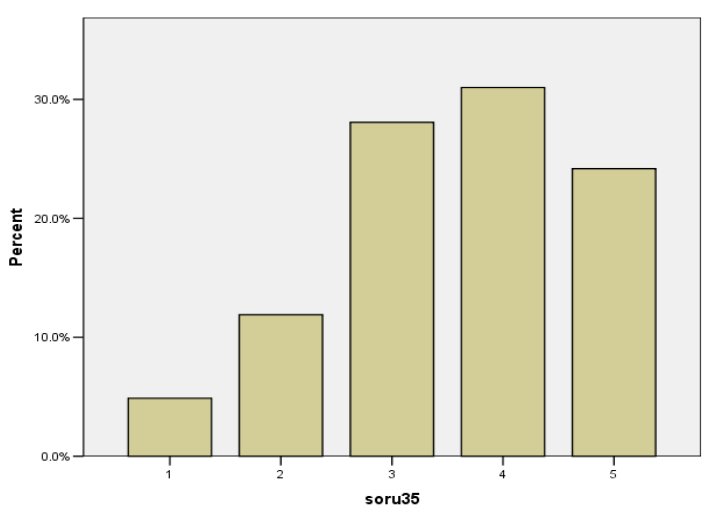

Figure 17. Should case studies and role playing be implemented extensively for accounting courses?

Q37: Should internship be definitely included for accounting education?

$5.3 \%$ of students definitely disagree, $9.4 \%$ disagree, $24.4 \%$ are indecisive, $28.1 \%$ agree and $32.9 \%$ do definitely agree.

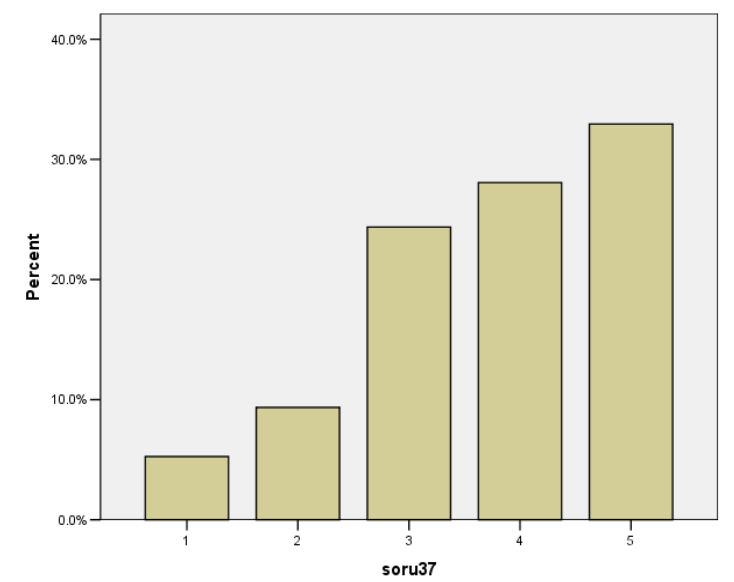

Figure 18. Should internship be definitely included for accounting education?

\section{Conclusion}

The results of our research lead us to draw important conclusions. First of all, the study shows that Turkish Commercial Code and Turkish Accounting Standards do 
not exist as mandatory or elective courses in the curriculums of universities in general. Secondly, most of the students believe that, it will be beneficial to include courses related to Turkish Commercial Code and Turkish Accounting Standards to curriculums of universities.

Thirdly, students in general are indecisive about the ratio of Turkish Commercial Code and Turkish Accounting Standards courses to all courses in the curriculums. In other words, they can not decide if the rate is sufficient of not. Again, university students in general can not decide if Turkish accounting academicians provide detailed information about Turkish Commercial Code and Turkish Accounting Standards in the courses.

A great majority of university students have indicated that, it is advantageous for them to gather a deep knowledge of Turkish Accounting Standards and Turkish Auditing Standards in the courses. Then, a high percentage of students have stated that they are indecisive about the fact that they are getting detailed information on Turkish Accounting Standards and Turkish Auditing Standards in their courses. Furthermore, a great number of students have emphasized that, they should be familiar with professional accounting standards and auditing standards through their education.

In addition, parallel to thoughts and perceptions of most students in Turkey, financial (general) accounting courses do include some topics and elements of international accounting. Moreover, most of the students in Turkey underlined the fact that, contemporary accounting issues and topics are discussed in classrooms. After that, a high majority of univerity students in Turkey have pointed out that, they believe accounting education should focus on national and international exams designed for employment opportunities.

Next, most of the students have mentioned that, accounting education should focus more on analysis and interpretation compared to recording of transactions. Plus, a high ratio of students have stressed that, they believe the accounting education should focus more on the ethical concepts. Thus, according to most university students in Turkey, the ethical dimension in accounting courses are not discussed adequately.

Then, most university students in Turkey think that, education technique based on cases and role playing should be implemented more through accounting courses. Finally, according to most university students in Turkey, internship is an essential part of accounting education.

\section{Limitations and Recommendations for} Future Research

Although the sample of our research includes 513 respondents from 9 different universities, we believe that the researchers can study a larger sample in the future since the number of Turkish state and private universities has increased tremendously in the recent years.

Also, similar researches can be run on academicians teaching accounting, Big4 auditing firms, CPAs, private sector and state sector accounting employees to gather a wider perspective of issue.

\section{REFERENCES}

Adhikari, A., Flanigan, M.A., Tondkar, R.H. (1999). "A survey of international accounting education in the US and some other countries", Journal of Accounting Education.

\section{AICPA (1998). "The CPA Vision Project”.}

Aktaş, R. (2013). "İlke Temelli Finansal Raporlama Standartları Nasıl Öğretilmeli? TFRS 10 Konsolide Finansal Tablolar Standardı Örneği”, Mali Çözüm Dergisi, Ocak-Şubat 2013, pp. 133-168.

Aljifri, K., Khasharmeh, H. (2006) "An investigation into the suitability of the international accounting standards to the United Arab Emirates environment", International Business Review, Vol. 15, No. 5, pp. 505-526.

AYBOĞA, H. (2002). "Globalleşme Sürecinde Muhasebe Alanındaki Gelişmelere Ülkemizin Uyumu", Balıkesir Üniversitesi Sosyal Bilimler Dergisi, http://www.sbe.balikesir.edu.tr/dergi/edergi/c5s8/makale/ c5s8m3.pdf

Ballas, A., D. Skoutela, and C. Tzovas. (2010). "The relevance of IFRS to an emerging market: evidence from Greece”. Managerial Finance, Vol. 36 Issue: 11, pp. 931-948.

Black, B.S., De Carvalho, A.G., Gorga, E. (2010). "Corporate governance in Brazil", http://papers.ssrn.com/sol3/papers.cfm?abstract_id=1152 454

Bui, B and Porter, B. (2010), The expectationperformance gap in accounting education: An exploratory study. Accounting Education: An International Journal, 19 (1-2), pp. 23-50.

Coetzee, S.A., Schmulian, A. (2012). "A Critical Analysis of the Pedagogical Approach Employed in an Introductory Course to IFRS", Issues in Accounting Education, Vol. 27, No: 1: pp.83-100.

Demir, V., Öztek Süer, Ö. (2006). “Avrupa Birliği'ne Giriș Sürecinin Türkiye'deki Muhasebe Eğitimine Etkileri", Muhasebe ve Denetime Bakış Dergisi, TÜRMOB Yayını, No: 20, 31-44.

Durak, G. (2009). "Üniversitelerde verilen muhasebe eğitiminin Kırklareli yöresi'nde faaliyet gösteren küçük ve orta büyüklükteki işletmelerin beklentilerini karşılama düzeyinin incelenmesi”, Trakya Üniversitesi SBE İşletme Anabilim Dalı Yüksek Lisans Tezi. 
Ezeani Nneka S., Rotimi, O. (2012). "Auditing as a Tool for Accountability for Efficient and Effective School Administration.” Arabian Journal of Business and Management Review (OMAN Chapter) 5, pp. 48-55.

Fowler, M., Tan, L., Hawkes, L. (2002). "Management accounting education: Is there a gap between teaching and practice?" Chartered Accountants Journal of New Zealand. Vol. 81, No:10, pp.58-62.

Garuba, A. O.,Donwa, P. (2011). "The challenges of Adopting international financial Reporting system in Nigeria”, JORIND I (9). pp. 313-317.

Gökçen G., Akgül, B. A., Cakıc1, C. (2006). "Türkiye Muhasebe Standartları Uygulamaları", Beta Basım Yayım.

Gökgöz, A. (2007). "Ticaret Meslek Liselerinde Muhasebe Eğitimi Alan Öğrencilerin Stajyerlikte Karşılaştıkları Problemleri ve Çözüm Öneileri: İstanbul Örneği”. Sakarya Üniversitesi SBE Yüksek Lisans Tezi.

HOWIESON, B. (2003). "Accounting Practice In The New Millenium : Is Accounting Education Ready To Meet The Challenge?", The British Accounting Review, 35, pp.99-103.

ICAA, The Institute of Chartered Accountants in Australia. (1998). "The Vision 2020 Taskforce Report: Chartered Accountancy in the Next Century - Radical Change or Diminished Influence?"

ICAEW. (1996).“Added-Value Professionals: Chartered Accountants in 2005 (Report)”, London.

IFAC. (2005). "Code of Ethics for Professional Accountants." Revised in June.

Jackling, B., Howieson, B., Natoli, R. (2012). "Some Implications of IFRS Adoption for Accounting Education, Australian Accounting Review, Vol. 22., Issue: 4

Jermakowicz, E.K., Gornik-Tomaszewski, S. (2006) "Implementing IFRS from the perspective of EU publicly traded companies", International Accounting, Auditing and Taxation, Vol. 15, pp.170-196.

Jones, S., Higgins, A. D. (2006) “Australia's switch to international financial reporting standards: a perspective from account preparers", Accounting \& Finance, Vol. 46, pp. 629-652.

Karğın, M., Aktaş, R., "UFRS'ye Geçiş Sürecinde Yükseköğretimde Muhasebe Eğitiminin Değerlendirilmesi”, Uluslararası Türk Coğrafyasında UFRS Sempozyumu, Trabzon, Turkey, 16 -17 June 2012.

Kızıl, A., Fidan, M. M., Kızıl, C., Keskin, A. İ. (2013). "TMS - TFRS, Türkiye Muhasebe ve Finansal Raporlama Standartlar1: Uygulamalar, Yorumlar, Muhasebeleştirme", DER Publishing.
KPMG and American Accounting Association, (2011). "2011 KPMG/AAA IFRS in the Accounting Curriculum Survey", KPMG Official Website (Amr.KPMG.com),

https://clients.amr.kpmg.com//facultyportal//NR//rdonlyr es//2F117EDE-EE64--4C87--9EEE-F02DAF3B7A09//0// 2011KPMG_IFRS_FacultySurvey.ppt.

Leone, M. 2008, 'Dying for a Date'. Available at:http://www.cfo.com//article.cfm//11566491//c_298436 8//?f=archives, 1 March 2012

Malone, F. (2006). "The ethical attitude of accounting students". Journal of the American Academy of Business 8 (March). pp. 142-146.

Marshall, P. D., Dombrowski, R., Garner, M., Smith, K. (2010). "The Accounting Education Gap". The CPA Journal. 6-10.

Miller, G. J., Daniker, V., Ralmond, P. V. (1999). "Trends in Government Accounting Education Approaching the New Millennium - A survey was conducted to uncover the changes that have taken place in government accounting education during the past five years and those that will occur in the coming years", The Government Accountants Journal, Vol. 48., pp.12-19.

Mintz, S.M. 2009, 'The Impact of IFRS on Accounting Professionals and Accounting Education', Today's CPA , November/December: 24-7.

Munter, P. and Reckers, M.J. 2009, 'IFRS and Collegiate Accounting Curricula in the United States: 2008 A Survey of the Current State of Education Conducted by KPMG and the Education Committee of the American Accounting Association', Issues in Accounting Education, Vol. 24 Issue: 2, p.131.

Örten R., Kaval, H., Karapınar, A. (2007). "Türkiye Muhasebe-Finansal Raporlama Standartları, TMS-TFRS", Seçkin Publishing.

Pekdemir, R., Türel, A. G., "Ethics in Professional Accounting Education Program: The Turkey Experience", Accounting Studies in Turkey, Pekdemir R., Ed., İstanbul Üniversitesi İșletme Fakültesi Muhasebe Enstitüsü, Istanbul, pp.63-77, 2010.

Preobragenskaya, G. G., McGee, R. W., (2003a). "International Accounting Standards and Foreign Direct Investment in Russia",Presented at the International Trade and Finance Association's Thirteenth International Conference, Vaasa, Finland, May 28-31, 2003.

Preobragenskaya, G. G., McGee, R. W. (2003b). "The Current State of Auditing in Russia". In Jerry Biberman \& Abbass F. Alkhafaji (Eds.), Business Research Yearbook: Global Business Perspectives, Volume X (pp.499-503) Saline, MI: McNaughton \& Gunn, Inc. 
Rothbard, M. N. (1991). "The Case for a 100 Percent Gold Dollar". Ludwig von Mises Institute.

Sennholz, H. (2002). "Russia's March from Communism", Mises Institute.

Stolowy, H., Tenenhaus, M. (1997).”International Accounting Education in Western Europe", HEC School of Management.

Süer, H. M. (2007) "Ticaret Meslek Liselerinde Muhasebe Eğitimi, Muhasebe Eğitiminden Beklentiler ve Karşılaşılan Sorunlar", Yayınlanmamış Yüksek Lisans Tezi, İstanbul Üniversitesi, Sosyal Bilimler Enstitüsü, İstanbul.

Tyrrall, D., Woodward, D., Rakhimbekova, A. (2007) "The relevance of International Financial Reporting Standards to a developing country: Evidence from Kazakhstan", The International Journal of Accounting, Vol. 42, No. 1, pp. 82-110.

Uyar, A., Güngörmüş, A. H. (2013). "Perceptions and knowledge of accounting professionals on IFRS for SMEs: Evidence from Turkey", Research in Accounting Regulation, Vol. 25, Issue: 1, pp. 77-87.

Yereli, A. N., Kayal1, C., Özdoğan, B., Gacar, A., Ata, F. İ. (2010), "Uluslar arası Muhasebe Eğitimi Literatür Taramas1: 1997-2008 Dönemi”, Ege Akademik Bakış Dergisi, Vol. 10, No:3, pp. 885-910.

Y1ldı, F. (2004). "Üniversitelerimizde Görev Yapan Muhasebe ve Finansman Öğretim Üyesi Yardımcı Doçentler ile İlgili Bir Araştırma”, Muhasebe ve Finansman Dergisi, Sayı: 24, pp.128-145. 